\title{
The differences in Probe Thinking Between Gifted and Non-gifted students with Learning Disabilities
}

\author{
Abdulnaser Abdulraheem Fakhrou \\ Faculty of education- Qatar university- State of Qatar
}

\begin{abstract}
.
The research aimed to study probe thinking among gifted and non-gifted male and female students with learning difficulties, as the probe thinking test was applied to a sample of 80 male and female students with learning difficulties from both boys and girls in government schools, and the research was carried out through an electronic test presented For teachers and parents, as the research results found that there are statistically significant differences between the gifted and the non-gifted with learning difficulties in favor of the gifted, and the research results showed that there are no differences between boys and girls in proactive thinking, and the research recommended attention to stimulating proactive thinking among students through teaching And classroom and extra-curricular activities, the research also recommended discovering and developing students 'talents in a way that stimulates their proactive thinking and making use of that in treating learning difficulties and improving academic achievement.
\end{abstract}

Keywords: probe thinking - Students with Learning disabilities - Gifted Students.

\section{Introduction.}

Probe thinking is considered an educational and life necessity for every individual in the conditions of the modern era. This is because probe thinking requires attention and awareness, linking educational experiences with each other, deducing relationships between knowledge and linking them to life experiences (Wang Meina et al, 2021), which is a style of thinking appropriate to the conditions of the modern era, which is called the information revolution, with the many experiences it has provided that require careful thinking to keep pace with Adverbs of the times.

The State of Qatar adopts a modern vision for the year 2030, the axis of human development being the most important of its four axes, and it requires achieving human development to qualify the individual to face the conditions of the times and benefit from what was provided by the information revolution (General Secretariat for Development Planning, 2008), which is provided by probe thinking in depth and contemplation of knowledge.

Probe thinking contributes to achieving the best rates of education and rehabilitation for people with disabilities, which is in line with Law No. (2) of 2004 signed by His Highness the Emir of Qatar Sheikh Hamad bin Khalifa Al Thani (website of the Arab Organization for Persons with Disabilities, 2021). 
Probe thinking is one of the modern thinking patterns that have been associated with the cognitive trend, which depends on concepts such as: cognitive structure and cognitive representations, as the owners of this trend assumed that the cognitive structure develops as a result of the interaction that takes place between the learner and what he encounters, and not what is being indoctrinated to him. All of this determines the developmental stage that he is going through. (Sternberg, 1994, pp: 36-40)

Probe thinking is one of the higher thinking skills, as it includes the use of higher and complex mental processes that help us to interpret, analyze and treat information to answer a question or solve a problem that cannot be solved by using lower thinking skills, issuing judgments, giving opinions, and using multiple criteria to reach the result (Muhammad Khalifa Al-Shuraidah Mowafak Salim Bishara: 2010, 229-230).

The study of Wisal Muhammad Salem (2012) indicates that there is a group of gifted students with learning difficulties in our Arab schools that do not receive sufficient attention, which requires knowledge of the characteristics of this group of students. Likewise, proactive thinking if it is trained and improved upon among students with learning difficulties, It may improve aspects of their learning and develop their mental faculties.

The present study deals with researching probe thinking among students with learning difficulties gifted and ungifted and shows whether there is a difference between both categories in their proverbial thinking patterns, and shows the role of probe thinking in improving their aspects of thinking and giftedness.

\section{Research problem:}

Saber thinking is an educational and life necessity for every student who seeks excellence, and students with learning difficulties suffer from insufficient interest in the existence of their proactive thinking skills, even though they possess many abilities and thinking skills just like the ordinary. It makes it characterized by certain characteristics such as: internal motivation and real understanding of what he learns in addition to his ability to interpret, analyze and summarize, as he is also interested in the study material, learning and understanding it, as it links theoretical ideas with daily life experiences, all of which are necessary skills to treat learning difficulties. (Ali Abbas Al-Youssefi: 2009, 7-8) Likewise, (Yusef Qatami and Nayfah Qatami, 2000: 298) also indicate that proactive thinking includes other types of thinking such as: inductive and deductive thinking, and he adds (Mahmoud Muhammad Ghanem, 1995, 136) Saber thinking is also part of innovative thinking and is provoked by the use of probing questions.

Probe thinking helps in stimulating and improving the student's mental processes, as Walid Rafiq Al-Ayasrah (2011) points out that proactive thinking is one of the advanced mental processes that the individual employs in various fields and enables the learner individual to receive, process, analyze, classify, understand and refine data and then integrate it with the individual's cognitive structure. It also enables the learner to use the content of the course material to develop his knowledge, experiences and ideas to be able to generate new ideas that he can subject to analysis and trial in order to improve his performance in order to 


\section{ARERL}

4th International conference on Advanced

Research in Education, Teaching \& Learning

reach the stage of creativity, which are necessary skills for students with learning difficulties. (Walid Rafiq Al-Ayasrah B, 2011, 179)

Through the researcher perusal of the previous studies, the researchers found - within the limits of what they had seen - a severe dearth of Arab and foreign studies that dealt with the proactive thinking of gifted and untalented students with learning difficulties, which is what invited the researchers to conduct this study.

Gifted students from the category of learning difficulties are distinguished by the intellectual characteristics that distinguish them from their families with non-gifted learning difficulties, and the research problem is to answer the following main question:

What are the differences in proverbial thinking between gifted and non-gifted students with learning disabilities?

\section{This question gives rise to the following questions:}

1- What is the extent of proactive thinking patterns among gifted students with learning disabilities?

2- To what extent are there proverbial thinking patterns among untold students with learning disabilities?

3- What are the differences in probe thinking skills between gifted and non-gifted students with learning difficulties?

\section{research importance:}

\section{First - Academic importance:}

1- Developing a theoretical framework for the extent of proactive thinking among gifted students with learning difficulties.

2- Determine the differences in proactive thinking between gifted and untalented students with learning difficulties.

3- Determine and grade the patterns of proactive thinking of students with learning difficulties.

\section{Second - Application Objectives:}

1- Determining the deficiencies in proactive thinking skills for students with learning difficulties, both gifted and untalented.

2- Developing the necessary recommendations to improve the proactive thinking skills of students with learning difficulties, which is in line with Qatar Vision 2030 and the Convention on the Rights of Persons with Disabilities.

research aims:

1- Determining the proverbial thinking patterns of gifted students with learning difficulties.

2- Determining the proverbial thinking patterns of untold students with learning difficulties.

3- Identify the differences in proactive thinking between gifted and non-gifted students with learning difficulties. 


\section{Search terms:}

\section{Probe Thinking}

Both (Mustafa and Abdel-Hadi) defined it as a process aimed at arriving at inferences that start from careful observation, then perceptual perception, linking them to previous experiences in memory, and then arriving at proposals, conclusions and principles. (Jawdat Abd al-Hadi, 2007: 228).

Procedurally, the researcher determine it according to the overall score obtained by the student through his response to the paragraphs of the proxy thinking scale, prepared by Asim Abdul Majeed, 2016

\section{Gifted students with learning disabilities:}

(Cindy Perras, 2021) defined gifted students with learning difficulties as students who possess superior intellectual ability and show a great discrepancy between this potential and their level of performance in a specific academic field such as reading, mathematics, spelling or written expression, where their academic performance is much lower than what is Predicted based on their general intellectual ability.

The researcher define gifted students with learning difficulties as students with learning difficulties in government schools, who have medical reports in their files in integration schools that decide, and who have student talents according to a questionnaire and the talent reports in their files.

\section{Commentary on previous studies:}

By reviewing previous studies, it is clear to us that proactive thinking can be developed among superior students with learning difficulties As the study of Ihab Ahmed Muhammad Mukhtar (2016) showed that proactive thinking develops the reflective thinking skills necessary for talent and creativity as demonstrated by the study of Hessa bint Hassan Hasan Al-Harthi (2011) as well as a study on Zuhair Hassan (2015). She explained the effect of proactive thinking in the direction towards biology for students with scientific and natural talents.

\section{Researcher can enumerate the benefits of previous studies as follows:}

1- Proactive thinking is a skill needed for every gift.

2- Saber thinking is highly present in the intellectually gifted.

3- Proverbial thinking is present among all groups of students, including those with learning difficulties, but to varying degrees.

** It is evident from the foregoing that there is a dearth of studies that have dealt with proactive thinking among gifted and non-gifted students with learning difficulties.

\section{Study hypotheses:}

After reviewing the theoretical framework and previous studies, the researchers reached to formulate the following hypotheses for the study: 


\section{ARERL}

4th International conference on Advanced

Research in Education, Teaching \& Learning

- There are no statistically significant differences between the gifted and the non-gifted with learning difficulties in the performance on the probe thinking test.

- There are no statistically significant differences between gifted students with learning difficulties in performance on the probe thinking test due to the gender variable.

- There are no statistically significant differences between the non-gifted and those with learning difficulties in the performance on the probe thinking test due to the gender variable.

\section{Study procedures:}

\section{First - study tools:}

\section{Diagnostic tools:}

- Students with learning difficulties have been identified through their files in schools with the special education departments. As each student has a report from Hamad Hospital and Roua Center that states that the student is diagnosed in the category of learning difficulties.

- Confirmation of the convergence of students' intelligence scores was determined through the intelligence test reports (Wexler fourth edition) available in each student's file, where the average IQ scores were (93 according to the Wexler Intelligence Scale, Fourth Edition).

- The researcher sought the help of the Gifted Care Committee in each school, where the committee identified the names of students with gifted learning difficulties, the research sample.

\section{Basic tools:}

Probe thinking test prepared by Asim Abdul Majeed Kamel Ahmad (2020).

\section{Research Methodology:}

The current research uses the descriptive approach to measure and describe the proactive thinking of gifted and non-gifted students with learning difficulties.

\section{Temporal determinants of the search:}

The research was applied during the second semester of the 2020-2021 academic year

\section{Spatial determinants of the search:}

The research was applied to a sample of male and female students in government secondary schools that apply the integration system in the State of Qatar. 


\section{The research sample:}

The research was applied to a sample of students with learning difficulties (gifted and nongifted), whose statement is as follows table(!):

\begin{tabular}{|c|c|c|c|}
\hline Type of sample & Male & Female & Total \\
\hline Gifted students with learning disabilities & 20 & 20 & 40 \\
\hline $\begin{array}{l}\text { Students with learning disabilities who } \\
\text { are not gifted }\end{array}$ & 20 & 20 & 40 \\
\hline Total & 40 & 40 & 80 \\
\hline
\end{tabular}

\section{Conclusion}

\section{research results:}

With regard to the first hypothesis, which states that "there are no statistically significant differences between the gifted and the untolded with learning difficulties in performance on the proverbial thinking test", as the first hypothesis was found to be incorrect; For the existence of statistically significant differences between gifted students with learning difficulties and non-gifted students with learning difficulties in favor of gifted students. Where the value of (t.test) was 13.12, which is a function value at the 0.05 level.

Table No. (2) The difference in proactive thinking between gifted and non-gifted students with learning disabilities

\begin{tabular}{|c|c|c|c|c|c|}
\hline Sample type & $\mathrm{N}$ & Mean & s.d. & T.test value & $\begin{array}{l}\text { Indication } \\
\text { level }\end{array}$ \\
\hline $\begin{array}{l}\text { Gifted students with learning } \\
\text { disabilities }\end{array}$ & 20 & 76.1 & 6.78 & \multirow{2}{*}{13.12} & \multirow{2}{*}{$\begin{array}{c}\text { Function } \\
\text { value at } \\
.05\end{array}$} \\
\hline $\begin{array}{l}\text { Students with learning disabilities who } \\
\text { are not gifted }\end{array}$ & 20 & 44.95 & 3.31 & & \\
\hline
\end{tabular}

Table No. (3) illustrates the difference in proactive thinking between gifted and non-gifted students with learning disabilities

\begin{tabular}{|c|c|c|c|c|c|}
\hline Sample type & $\mathrm{N}$ & Mean & s.d. & T.test value & $\begin{array}{c}\text { Indication } \\
\text { level }\end{array}$ \\
\hline $\begin{array}{l}\text { Gifted students with learning } \\
\text { disabilities(female) }\end{array}$ & 20 & 65.85 & 9.90 & \multirow{2}{*}{8.49} & \multirow{2}{*}{$\begin{array}{c}\text { Function } \\
\text { value at } \\
.05\end{array}$} \\
\hline $\begin{array}{l}\text { Students with learning disabilities who } \\
\text { are not gifted(female) }\end{array}$ & 20 & 46.45 & 2.50 & & \\
\hline
\end{tabular}




\section{ARERL}

4th International conference on Advanced

Research in Education, Teaching \& Learning

It is clear from the previous table that there are differences in proactive thinking between gifted and untalented students with learning difficulties in favor of talented students, and this is consistent with the findings of previous studies, including the study of Nabil Kazem AlShammari 2018, the Diane 2015 study and the Hessah bint Hassan Al-Harithi study 2011, which corroborates the results of the current study.

** With regard to the second hypothesis, which states that "there are no statistically significant differences between gifted students with learning difficulties in performance on the proverbial thinking test due to the variable of sex."

Table (4) shows the differences in proactive thinking between gifted people with learning difficulties (boys and girls)

\begin{tabular}{|c|c|c|c|c|c|}
\hline Sample type & $\mathrm{N}$ & Mean & s.d. & T.test value & $\begin{array}{c}\text { Indication } \\
\text { level }\end{array}$ \\
\hline $\begin{array}{c}\text { Gifted students with learning } \\
\text { disabilities }\end{array}$ & 20 & 67.1 & 6.78 & & $\begin{array}{c}\text { Function } \\
\text { value at }\end{array}$ \\
\hline $\begin{array}{c}\text { Students with learning disabilities } \\
\text { who are not gifted }\end{array}$ & 20 & 65.85 & 9.90 & & .05 \\
\hline
\end{tabular}

The statistical analysis of the results of the second hypothesis reveals that there are no statistically significant differences in the gender variable between gifted male and female students with learning difficulties in relation to proactive thinking. Where both sexes (male and female students) possess proactive thinking skills to a large extent, and this is consistent with previous studies which see that proactive thinking is a necessary skill for the talent that requires reflection and linking of causes and factors, which are necessary skills for every talent.

- With regard to the results of the third hypothesis, which states that "there are no statistically significant differences between non-gifted people with learning difficulties in performance on the proverbial thinking test due to the variable of sex."

Table (5) shows the results of the statistical analysis of the third hypothesis

\begin{tabular}{|c|c|c|c|c|c|}
\hline Sample type & $\mathrm{N}$ & Mean & s.d. & T.test value & $\begin{array}{c}\text { Indication } \\
\text { level }\end{array}$ \\
\hline $\begin{array}{c}\text { students with learning } \\
\text { disabilities(Male) }\end{array}$ & 20 & 44.94 & 3.31 & & $\begin{array}{c}\text { Function } \\
\text { value at }\end{array}$ \\
\hline $\begin{array}{c}\text { Students with learning disabilities } \\
\text { (Female) }\end{array}$ & 20 & 46.45 & 2.50 & -1.61 & .05 \\
\hline
\end{tabular}

It is evident from the previous table that there are no statistically significant differences between male and female students with learning difficulties in proactive thinking, due to the participation of both sexes in the lack of talents as well as their suffering from learning difficulties.

\section{Discuss the results of the study:}


- Through the previous presentation of the statistical analysis of the results of the study, it becomes clear to us that the first hypothesis is incorrect, which states that "there are no statistically significant differences between the gifted and the un-gifted with learning difficulties in performance on the proverbial thinking test" as the results of the study showed that there are differences in proactive thinking Between gifted and non-gifted people with learning difficulties, for the benefit of the gifted (technically - mentally - socially - culturally mathematically ... etc.) and this may be explained by the fact that the gifted person has the characteristics and characteristics of proactive thinking, which is one of the pillars of a gifted person despite being with learning difficulties.

- Also by analyzing the results of the second hypothesis, which states that "there are no statistically significant differences between gifted students with learning difficulties in performance on the proverbial thinking test due to the gender variable" as the results of the study proved the validity of this hypothesis as it was found that there are no statistically significant differences In the results of the probe test between gifted and talented people with learning difficulties, and although these results are not consistent with the study of Nabil Kazem Al-Shammari 2018, which concluded that there are differences in proactive thinking between boys and girls in favor of boys, but the previous study sample did not include the category of (gifted) and thus we conclude That gifted boys and girls agree to possess proactive thinking skills in almost equal proportions.

- With regard to the third hypothesis, which states that "there are no statistically significant differences between the non-gifted and those with learning difficulties in the performance on the proverbial thinking test due to the gender variable" as the results of the study proved the validity of this hypothesis and this is consistent with the results of previous studies, due to the fact that The two groups are unanimous in lack of talent, as well as in learning difficulties.

\section{Recommendations and proposals of the study:}

In light of the results of the current study, the study recommends the following:

1- Training students in proactive thinking skills by explaining classroom and extracurricular lessons and activities to enrich their thinking skills.

2- Stimulating students 'thinking patterns to enrich their capabilities and develop their talents.

3- Preparing teachers to stimulate, motivate and develop students 'talents in a way that enriches their proactive thinking skills.

4- Using teaching methods that stimulate proactive thinking among students, along with treatment of learning difficulties.

5- To take advantage of the proactive thinking skills of gifted students to increase academic achievement of students with learning difficulties.

6- The study also recommends conducting similar research and studies on primary and middle school students. 


\section{References:}

- Abd al-Hadi J., (2007): Theories of learning and their educational applications, 1st Edition, Dar Al Thaqafa for Publishing and Distribution, Amman.

- Abd al-Muttalib, Amin al-Quraiti (2005). Psychology of people with special needs, Cairo, Arab Thought House.

- Abdel Fattah Fawqia (2004). Memory capacity, strategies and coding levels for a sample of elementary school students with reading difficulties and ordinary people, The Egyptian Journal of Psychological Studies, Volume 13, Issue 42, February, Cairo, The Anglo-Egyptian Library, 207-270.

- Abdulaziz Al-Sayyid Al-Person (1990). Gifted students in public education in the Arab Gulf states, methods of their discovery and means of caring for them, Arab Bureau of Education for the Gulf States, Riyadh, Kingdom of Saudi Arabia.

- Ali Abbas Al-Yousifi (2009). Methods of thinking and learning among students of the Faculty of Jurisprudence, Journal of the Islamic University, Najaf al-Ashraf, No. 55.

- Ali Zuhair Hassan, Uday Sabri Abdel-Razek and Imad Hussein Al-Morshedy (2015). The effect of using probing questions on achievement and tendency towards biology among second-grade intermediate students, Journal of the College of Education Basic for Educational and Human Sciences, Volume 1, Issue 24 (December 31, 2015), p. 402-420.

- Al-Qasim J., (2015). Basics of Learning Difficulties, Safaa House for Publishing and Distribution, Amman, Jordan.

- Al-Sharqawi A., (2002). Learning Difficulties, Problem, Symptoms, and Characteristics, Journal of Psychology, General Authority for Books, Cairo, July, 6-30.

- Amin I., Ali A., Abd al-Wahid H., (2014): “The Effect of Two Methods of Predicting Questions and the Achievement of Second-Grade Intermediate Students in the Arabic Language Grammar" Journal of the College of Islamic Education, University of Babylon, p. 15.

- Asim Abdel-Majeed Kamel Ahmed (2020) Probe Thinking Test, Cairo: The World of Books for Printing and Publishing.

- Baza A., (2016). Talent and mental superiority, Cairo, The Anglo Bookstore.

- Blumsack, J.; Lewandowsk, L.J \& Waterman, B.(1997). Neuro developmental Precursors to Learning disabilities: a preliminary report from apparent Survey. Journal of Learning Disabilities, 30(2), 228-237.

- Bob Schaffer, Randy Dehoff, Elaine Gantz Berman (2009). Twice - Exceptional Students Gifted students with disabilities level: 1 An introductory resource book, second edition, Colorado department of education. USA . 


\section{AREIL}

4th International conference on Advanced

Research in Education, Teaching \& Learning

- Cindy Perras(2021). Gifted Students with LDs: What Teachers Need to Know, Available at https://www.Idatschool.ca/gifted-students-with-lds-what-teachers-needto-know/

- Diane Marie Specht(2015).Probe Method's Impact on Students' Motivation and Critical Thinking Skills, Thesis of doctorate, Walden university, USA.

- Fatima Hamad, Khashman Ali (2012): "Proactive thinking and its relationship to the cognitive beliefs of university students", Tikrit University Science Journal, November, Volume 19, Issue 99, 483 - 555.

- Hessa bint Hassan Al-Harithi (2011). The Impact of Predicting Questions on the Development of Reflective Thinking and Academic Achievement in the Science Course of First Intermediate Students in the City of Makkah Al-Mukarramah, Master Thesis, College of Education, Umm Al-Qura University, Kingdom of Saudi Arabia.

- Kawafah K.,(2011). Learning difficulties and the proposed treatment plan, Dar Al Masirah for Publishing and Distribution, Amman, Jordan.

- Khalifa, Batoul Mohiuddin and Al-Ziyoud, Nader Fahmy (2008) Factors related to learning difficulties in the primary stage and their relationship to some variables, The Arab Journal of Special Education, Issue Twelve, Riyadh, pp. 111-159.

- Koh, (2002): Towards a critical pedagogy: creating thinking schools in singa pore, Journal of curriculum studies, 34(3), 255:264.

- Mahmoud Muhammad Ghanem (1995): “Thinking about a Child: Its Development and Teaching Methods", Dar Al-Fikr, Amman, Jordan.

- Muhammad Al-Shuraida, Mowafak Bishara (2010). Complex thinking and its relationship to some variables, a field study on students of Al-Hussein Bin Talal University, Damascus University Journal, Vol. 26, P3.

- Mukhtar I., (2016). The effectiveness of a program based on metacognitive strategies in developing proactive thinking skills and memorization habits of superior students with learning difficulties in high school physics, Journal of Arab Studies in Education and Psychology, Issue 75, pp. 173-224.

- Nabil Abdel Hady, Walid Ayyad (2009). Strategies for learning thinking skills between theory and practice, Wael Publishing and Distribution House, Amman, 1st floor, Amman, Jordan.

- Nabil Kazem Al-Shammari (2018), Saber thinking among university students, Basra Research Journal for the Humanities, Issue (3) C, Volume 43, pp. 116-138.

- Nayfeh Qatami (2003). Teaching Thinking Skills for the Basic Stage, Amman: First Edition, Dar Al-Fikr for Printing, Publishing and Distribution, Jordan.

- Ramadan Abdel-Hamid Al-Tantawi (2008). The Gifted: Methods of Nurturing them, and Their Teaching Methods, Amman, Dar Al Thaqafa for Publishing and Distribution. 


\section{ARERL}

4th International conference on Advanced

Research in Education, Teaching \& Learning

- Saadeh J.,(2009): “Teaching thinking skills with hundreds of practical examples, Dar Al Shorouk Publishing and Distribution, Amman, Jordan.

- Sabah Khalil (2016). The Effect of Predicting Questions on the Achievement of Literature by Students of the Kurdish Language Department in the College of Education / Ibn Rushd for Human Sciences, Journal of Educational and Psychological Research, Iraq, Issue (48), 346-369.

- Safaa Ahmed (2012). An effective study between the use of the medium-enrichment strategy and mental capacity and its effect on the transmission of the effect of learning and the development of proactive thinking and emotional intelligence among sixthgrade students, Journal of the Educational Association for Social Studies, Egypt, No. (46), 195-246.

- Sherine Abdel Fattah, Hana Othman (2016) The effect of using the proverbial thinking model in developing some scientific concepts in pre-school children, Journal of Scientific Education, Egypt, Volume (19), Issue (4), 85 - 134.

- Sternberg,. (1994). Allowing for Thinking Styles. Educational Leadership. Vol.52, N.3, $.36-40$.

- Suleiman Abdel-Wahid Youssef Ibrahim (2010). The reference in developmental, academic, social and emotional learning difficulties, The Anglo-Egyptian Library, Cairo.

- Suleiman Abdel-Wahid Yusef Ibrahim (2007). Brain and Learning Difficulties: a vision in the context of cognitive psychology, The Anglo-Egyptian Library, Cairo.

- The General Secretariat for Development Planning (2008). Qatar's vision for the year 2030, available at https://www.diwan.gov.qa/about-qatar/qatar-national-vision2030?sc lang=en-QA

- Tishman, (2008): the concept of thinking sounding probe thinking concept, the International Journal of Research and Review, Volume 21, issue 5.

- Wafaa Karim (2008). The Effect of Effective Questions Strategy on the Development of Probing Thinking among Kindergarten Children, MA, College of Basic Education, Al-Mustansiriya University, Iraq.

- Walid Al-Ayasrah A (2011). Saber and Creative Thinking, Usama Publishing and Distribution House, Amman, Jordan.

- Wang Meina, Wu Fan ,Meng Kaining and Luo Yang(2021). A Probe into Cultivation Path of Students' Ability in Innovative Digital Technology Design Based on Design Thinking, 3rd International Conference on Energy Resources and Sustainable Development (ICERSD 2020),Available at https://doi.org/10.1051/e3sconf/202123605075 
- Yahya Al-Qabali (2017) Learning Difficulties Definition, Diagnosis and Treatment, Gulf House for Publishing, Oman.

- Yusef Qatami, Nayfa Qatami (2000): "The Psychology of Classroom Learning", Dar Al Shorouk for Publishing and Distribution, Amman, Jordan.

- Zainab Mahmoud Choucair (2004). Call from the physically - behaviorally - physically educational disabled son, 2nd floor, Cairo, The Egyptian Renaissance Library. 